\title{
Perbanyakan dan Penyebaran Bibit Ternak Domba Compass Agrinak Mendukung Perekonomian Peternak
}

\author{
Propagation and Distribution of Agrinak Compasss Sheep Seedlings to Support Farmers' Economies
}

\author{
S. Rusdiana dan U. Adiati \\ Balai Penelitian Ternak Ciawi-Bogor PO.Box. 221. Bogor-Jawa Barat \\ Corresponding Author: $\underline{\text { s.rusdiana20@gmail.com }}$
}

\begin{abstract}
The study was to find out the propagation and distribution of Agrinak Compass sheep breeds supporting the economy of farmers. The research was conducted in Pandansari Village UPTD, Paguyangan District, Brebes Regency, Central Java in 2017. Research collaboration in the umbrella of the MoU, and its contents contained the rights and obligations of each party. Research collaboration for the development of agrinak Compass sheep is a seed that can be disseminated to farmers. There were 10 agrinak Compass sheep, 8 adult females and 2 adult males. Primary data and secondary data were then analyzed quantitatively, qualitatively and economically. The results showed that the body weight of young ewes was $71 \pm 13 \mathrm{~g} /$ day. The body weight gain of 1 month old pre-weaned sheep was $145 \pm 53 \mathrm{~g} /$ head. The body weight of the sheep during pregnancy was $75 \pm 29 \mathrm{~g} /$ day. Capital expenditure and production costs incurred by the UPTD can generate profits of IDR 1.200.000.-/year, with $\mathrm{B} / \mathrm{C}$ ratio of 1.2. The capital expenditure and production costs incurred by breeders can produce a yield of IDR 620.000,-/year with B/C value of 1.2. Economically, agrinak Compass sheep were suitable for multiplying and disseminated to farmers. The business of sheep owned by farmers was economically not feasible, because the main business of farmers were farming.
\end{abstract}

Key words: multiplication, sheep seeds, support the farmers

\begin{abstract}
ABSTRAK
Tujuan penelitian untuk mengetahui perbanyakan dan penyebaran bibit domba Compasss Agrinak mendukung perekonomian peternak. Penelitian dilakukan di UPTD Desa Pandansari Kecamatan Paguyangan Kabupaten Brebes Jawa Tengah tahun 2017. Penelitian kerjasama di payungi MoU, isinya memuat hak dan kewajiban masing-masing pihak. Kerjasama penelitian untuk pengembangan domba Compass Agrinak sebagai bibit yang dapat disebarluaskan kepada peternak. Domba Compass Agrinak sebanyak 10 ekor, 8 ekor betina dewasa dan 2 ekor jantan dewasa. Data primer dan data sekunder kemudian dianalisis secara kuantitatif, kualitatif dan analisis ekonomi. Hasil penelitian menujukkan bahwa, pertambahan bobot badan domba betina muda sebesar $71 \pm 13$ $\mathrm{g} /$ hari. Pertambahan bobot badan domba anak pra sapih umur 1 bulan sebesar $145 \pm 53 \mathrm{~g} / \mathrm{ekor}$. Pertambahan bobot badan domba induk selama kebuntingan sebesar $75 \pm 29 \mathrm{~g} / \mathrm{hari}$. Biaya belanja modal dan biaya produksi yang dikeluarkan oleh UPTD dapat menghasilkan keuntungan sebesar Rp.1.200.000,-/tahun nilai B/C ratio 1,2. Biaya belanja modal dan biaya produksi yang dikeluarkan oleh peternak dapat menghasilkan keuntungan sebesar Rp.620.000,-/tahun nilai B/C 1,2. Secara ekonomi domba Compass Agrinak layak untuk diperbanyak dan disebarluaskan kepada peternak. Domba milik peternak secara ekonomi belum layak, karena peternak usaha pokoknya adalah bertani.
\end{abstract}

Kata kunci: perbanyakan, bibit domba, mendukung perekonomian peternak

\section{PENDAHULUAN}

Ternak domba sudah dikenal di masyarakat Indoneisa, dan banyak diusahakan oleh peternak kecil di pedesaan, mudah dipelihara dan mudah dijual. Domba dapat dikembangkan untuk produksi daging, kulit, dan bulu. Secara umum peternakan domba di Indonesia masih difokuskan untuk menghasilkan daging. Siklus reproduksi relatif singkat, dan domba merupakan ternak yang lebih tahan terhadap berbagai penyakit (Almahdy et al., 2000; Lupton, 2008). Usaha domba di pedesaaan merupakan komponen yang sangat penting, karena dapat membantu perekonomian peternak, mudah dijadikan sumber uang pada saat dibutuhkan. Misi Badan Litbang Pertanian, menemukan dan 
membangun inovasi pertanian (teknologi, kelembagaan dan kebijakan) yang maju dan strategis melalui penyediaan materi maupun teknologi. Dasar pemikiran bahwa inovasi peternakan yang dapat diadopsikan kepada para pengguna, sebagai kerja untuk perbanyakan dan penyebaran domba ke pada masyarakat peternak.

Domba merupakan salah satu jenis ternak ruminansia, memiliki karakteristik yang khas, baik dalam proses pencernaan makanan, berproduksi menghasilkan anak (Suhardi 2010). Penyebaran domba Compasss Agrinak hasil penelitian dapat disebarluaskan kepada masyarakat peternak, agar dapat diusahakan dengan baik, peternak dapat meningkatkan pendapatannya. Namun domba yang disebarluaskan harus spesifik lokasi, sesuai dengan lingkungan, sehingga domba dapat berkembang dengan baik. Sampai saat ini Badan Litbang Pertanian telah menghasilkan banyak teknologi. Namun terjadi gap antara teknologi yang tersedia dibandingkan dengan teknologi yang diaplikasikan di masyarakat. Oleh karena itu dibutuhkan akselerasi pemanfaatan teknologi melalui komunikasi antara lembaga penelitian dengan Dinas terkait. Teknologi dapat mengalir dengan baik ke para peternak, sehingga akan diperoleh feedback dari pengguna khususnya peternak.

Domba Compass Agrinak, merupakan salah satu rumpun ternak hasil rekayasa teknologi breeding Balai Penelitian Ternak. Penelitian dan inovasi domba Agrinak, merupakan hasil penelitian yang dilakukan dalam kurun waktu yang cukup panjang lebih dari $>25$ tahun, lima generasi. Pada tanggal 13 Oktober 2014 Menteri Pertanian melalui SK Mentan Nomor 1050/Kpts/SR.120/ 10/2014 tentang Pelepasan Rumpun Domba Agrinak, yang sebelumnya dinamakan domba Komposit Sumatera. Dengan dilepasnya rumpun domba, maka merupakan kewajiban moral bagi instansi Balitnak untuk mengembangkan dan menyebarluaskan ke peternak atau masyarakat. Kegiatan perbanyakan dan penyebaran bibit domba dapat dilakukan dengan berbagai metode yaitu introduksi melalui pola kelembagaan kampung domba (Isbandi, 2013). Penyebarluasan domba hasil penelitian dapat dilakukan melalui perusahaan peternakan, UPBS, dan langsung ke peternak. Salah satu yang belum pernah dilakukan yaitu pola dengan kerjasama dengan Dinas Peternakan Kesehatan Hewan Kabupaten Brebes melalui UPT/UPTD (Unit Pelaksana Teknis/Unit Pelaksana Teknis Dinas).

Berdasarkan permasalahan tersebut ditas, maka UPT/UPTD sebagai lokasi perbibitan dan merupakan lembaga yang tupoksinya khusus sebagai perbanyakan dan penyebaran bibit domba. Permasalahan yang sering dihadapi oleh lembaga diantaranya, masalah modal, komoditas ungggulan daerah di wilayah bersangkutan. Demikian apabila ada niatan yang besar (goodwill) pejabat yang dilandasi dengan potensi wilayahnya, seyogyanya hambatan tidak akan terjadi. Mengindikasikan bahwa pengembangan komoditas domba Compass Agrinak di Brebes sangat potensial untuk dilakukan. Tujuan penelitian ini adalah untuk mengetahui perbanyakan dan penyebaran bibit domba Compass Agrinak (CA) untuk mendukung perekonomian peternak.

\section{MATERI DAN METODA}

Kegiatan penelitian ini dilakukan di Unit Pelaksana Teknis/Unit Pelaksana Teknis Dinas (UPT/UPTD) Desa Pandansari Kecamatan Paguyangan Kabupaten Brebes Jawa Jawa Tenga,pada tahun 2017. Tepatnya di lembaga UPTD Dinas Peternakan dan Kesehatan Hewan Kabupaten Brebes. Kegiatan kerjasama ini di payungi MoU, dengan isinya memuat hak dan kewajiban masing-masing pihak. Klausulnya kesepakatan bersama bahwa, Dinas Peternakan dan Kesehatan Hewan Kabupaten Brebes mnyediakan lokasi dan lahan, dan Balai Penelitian Ternak Bogor (Balitnak) menyediakan domba Compass Agrinak dan anggaran untuk penelitian. Tujaan kegiatan kerjasama penelitian ini adalah untuk mengembangkan domba Compass Agrinak sebagai bibit yang dapat disebarluaskan kepada masyarakat peternak. Penelitian 
kerjasama untuk periode $>2$ tahun, dan untuk anggaran penelitian dianggarkan setiap tahun anggaran oleh Balitnak dan Dinas Peternakan dan Kesehatan Hewan Brebes.

Anggaran yang dialokasikan sesuai dengan kebutuhan menurut SOP pemeliharaan domba Compaas Agrinak yaitu : untuk bibit, pakan, kandang, dan biaya lainnya. Tahun pertama biaya pakan konsentrat dan obat-obatan dianggarkan oleh Balitnak. Tahun ke dua dan selanjutnya biaya yang dianggarkan dari Balitnak yaitu hanya biaya untuk pendampingan dan monitoring. Domba yang dikerjasamakan sebanyak 10 ekor domba Compass Agrinak, 8 ekor betina dewasa dan 2 ekor jantan dewasa. Domba tersebut akan dikembangkan di UPTD Brebes, dengan manajemen menurut SOP perbibitan, sehingga mampu menghasilkan bibit domba Compass Agrinak. Produksi bibit domba, akan dikembangkan ke masyarakat peternak sesuai dengan program di suatu wilayah yang telah ditetapkan. Sebagai pembanidng perkembangan domba Compass Agrinak, diambil data domba di lokasi peternak sekitar UPTD Brebes. Domba Compass Agrinak yang di UPTD dan domba mlik peternak diamati yaitu kinerja produksi dan reproduksi ternak.

Produktivitas induk domba diukur pula sifat-sifat reproduksi, bobot badan kawin, bobot badan setelah beranak, jumlah anak sekelahiran dan daya hidup anak prasapih. Rusdiana dan Rijanto (2014) menyatakan bahwa, untuk menentukan keuntungan peternak dapat dihitung berdasarkan biaya produksi usaha dan pendapatan hasil penjualan domba. Untuk menghitung nilai ekonomi pada usaha pemeliharaan domba Compasss Agrinak dapat dihitung dengan B/C. Sebagai pembanding pada nilai ekonomi ternak domba, maka dianalis nilai ekonomi usaha domba milik peternak dan Intensitas pemberian pakan ternak domba, baik di UPTD maupun di peternak. Nilai ekonomi dapat diperoleh dari hasil penjualan domba Compass Agrinak dan domba milik peternak berdasarkan harga beli dan harga jual.

\section{HASIL DAN PEMBAHASAN}

\section{Kondisi Umum Wilayah Kabupaten Brebes}

Wilayah Kabupaten Brebes termasuk, salah satu Kabupaten yang mempunyai daya dukung untuk pengembangan pertanian dan peternakan. Kondisi lingkungan berimplikasi pada kisaran temperatur beriklim panas hingga ke sangat dingin. Rata-rata penduduk di Kabupaten Brebes bekerja di bidang pertanian, dapat dilihat limbah hasil produksi pertanian jerami padi sebanyak 1.809.348 ton/ha, jerami jagung sebanyak 70.205 ton/ha, daun ketela pohon sebanyak 12.025 ton/ha, daun ketela rambat sebanyak 3.975 ton/ha, jerami kedelai sebanyak 8.567 ton/ha, daun kacang tanah sebanyak 2.037 ton/ha, daun tebu sebanyak 89.551 ton/ha, rumput lapangan sebanyak 453.574 ton/ha serta rumput unggul sebanyak 22.329 ton/ha. Artinya dapat mendukung untuk perkembangan domba Compass Agrinak (Dinas Peternakan dan Kesehatan Hewan Kabupaten Brebes 2017). Penyerahan domba Compass Agrinak ke Dinas Peternakan dan Kesehatan Hewan Kabupaten Brebes dilaksanakan pada tanggal 6 Agustus 2017.

\section{Pemberian Pakan Domba di Lokasi Penelitian}

Penyediaan pakan ternak domba, merupakan salah satu faktor penentu untuk perkembangbiakan ternak. Pemebrian pakan ternak domba sangat bervariasi, dan sesuai dengan tujuan usaha. Biasanya pemeliharaan domba secara intensif dikandangkan terus menerus oleh peternak. Usaha domba komersial penggemukan dikandangan terus menerus selain pakan hijauan juga pakan konsentrat. Pemberian pakan ternak domba di UPTD Brebes, dengan memanfaatkan limbah tanaman pangan, seperti jagung, kacang kedele, dan limbah pertanian lainnya. Pada awal tahun 2017 telah diintroduksikan hijauan pakan ternak domba di BPP Brebes. Intensitas pemberian pakan hijauan untuk domba baik milik UPTD mapun milik peternak terlihat pada Tabel 1. 
Tabel. 1. Jenis hijauan sebagai pakan domba di lokasi penelitian

\begin{tabular}{llcc}
\multirow{2}{*}{ No } & \multicolumn{2}{c}{ Jenis pakan } & \multicolumn{2}{c}{ Intensitas pemberian pakan } \\
\cline { 2 - 4 } & & di lokasi UPTD & domba milik peternak \\
\hline 1. & Rumput gajah & $* * *$ & $*$ \\
2. & Rumput lapang & $* *$ & $* * *$ \\
3. & Limbah sayuran & $*$ & $* *$ \\
4. & Limbah jermai jagung & $*$
\end{tabular}

Keterangan : $* * *=$ pemberian pakan setiap hari $* *=$ pemberian satu kali sehari hari $*=$ pemberian sewaktuwaktu pada saat panen

Tabel 1 menunjukkan pemberian pakan ternak domba, tergantung pada kondisi dan ketersediaan pakan. Pengalaman peternak, bahwa intensitas pemberian pakan yang paling sering diberikan adalah rumput lapangan. Jenis dan volumenya bervariasi, sehingga dipengaruhi oleh lokasi tempat perolehan rumput atau pakan. Hasil wawancara dengan petugas UPTD dan beberapa peternak setempat, menunjukkan bahwa tanaman sayuran sangat potensial sebagai penghasil limbah yang dapat dijadikan hijauan pakan ternak. Dari 1 ha lahan sayuran dapat diperoleh 2-3 ton, dapat dimanfaatkan sebagai pakan ternak domba. Desa Pandansari terdapat sekitar 770 ha lahan yang digunakan untuk usahatani sayuran. Jenis sayuran yang paling diminati adalah kentang, wortel dan kubis. Terlihat bahwa terdapat dua macam pola tanam sayuran yang umum dijumpai di Desa Pandansari, terlihat pada Gambar 1.

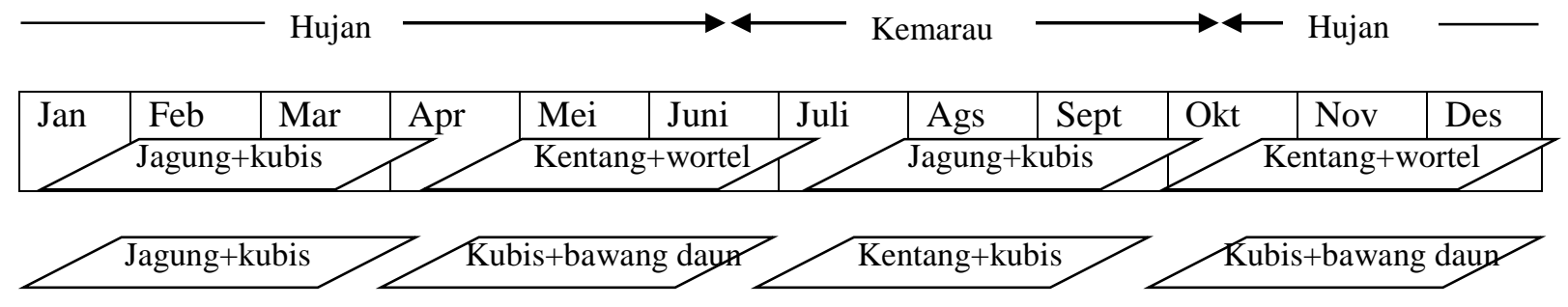

Gambar 1. Pola tanam, sayuran dan palawija di Desa Pandansari

\section{Perkembangan Domba (Dara)}

Lokasi penelitian domba diamati perkembangannya, dengan manajemen sesuai dengan SOP perbibitan. Pemberian pakan dan penyediaan pakan ternak domba sepeti rumput lapang dan limbah hasil pertaian, diberikan secara ad libitum disesuaikan dengan kebutuhan. Hasil perhitungan mengindikasikan bahwa konsumsi bahan kering mencapai $2,82 \%$ dari bobot badan, dari konsumsi sebanyak $52 \%$ diantaranya bersumber dari hijauan dan $48 \%$ diantaranya bersumber dari konsentrat. Pertambahan bobot badan domba dara menunjukkan rataan pertumbuhan sebesar $71 \pm 13$ g/ekor per hari. Hasil yang dicapai pada penelitian ini lebih tinggi dibandingkan dengan hasil yang di laporkan oleh Hendiwirawan et al., 2012, rataan pertambahan bobot badan harian pasca sapih domba muda Komposit Garut, Komposit Sumatera berturut-turut sebesar
63,80, 61,45 g/hari. Pertambahan bobot badan domba Compass Agrinak dara, terlihat pada Gambar 1.

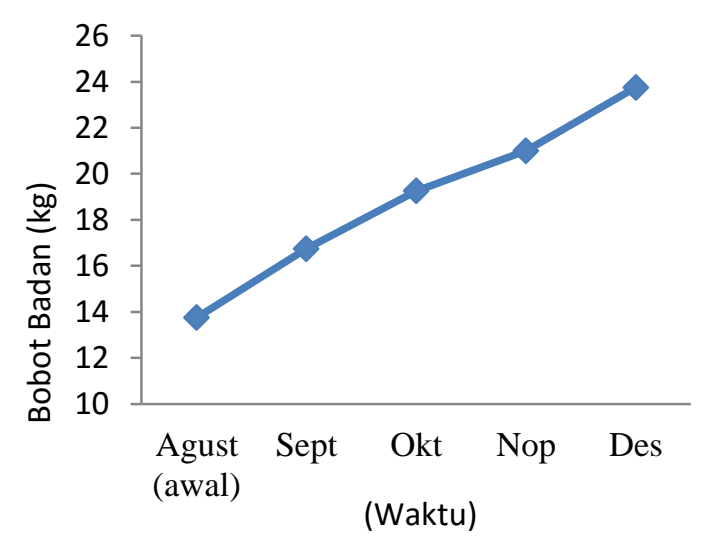

Gambar 1. Perkembangan bobot badan domba CA betina dara di lokasi kajian 


\section{Ternak Domba Compass Agrinak Induk}

Penambahan bobot badan domba terus meningkat, rataan pertambahan bobot badan selama kebuntingan sebesar $75 \pm$ 29g/hari. Rendahnya produktivitas pada domba biasanya disebabkan oleh rendahnya kualitas pakan yang diberikan (Mubarok et al., 201). Hasil yang dicapai pada pengamatan ini lebih tinggi dari penelitian (Handarini et al., 2016) pertambahan bobot badan domba lokal saat bunting sebesar $40.25 \pm 5,57 \mathrm{~g}$. Hasil penelitian Santi (2011) menunjukkan bahwa, pertambahan bobot badan domba induk bunting sebesar 38,33g/ekor/hari. Hasil penelitian Wardhani (2006) pada domba induk yang digembalakan dan diberikan tembahan pakan dedak padi pertambahan bobot badan sebesar $47 \mathrm{gr} / \mathrm{ekor} / \mathrm{hari}$. Hasil penelitian Saputra (2008) induk domba dipelihara secara ekstensif tanpa mendapatkan pakan tambahan rata-rata pertambahan bobot badan sebesar 69,9 g/ekor/hari, lebih tinggi dari rataan PBB pada penelitian Gopar (2012) sebesar 3.88 \pm 0.85 g/ekor/hari. Kondisi ternak domba induk Compass Agrinak (CA) pertambahan bobot badan lebih tinggi. Perubahan bobot badan domba selama bunting, saat melahirkan dan awal laktasi domba CA di lokasi kajian ditunjukkan pada (Gambar 2).

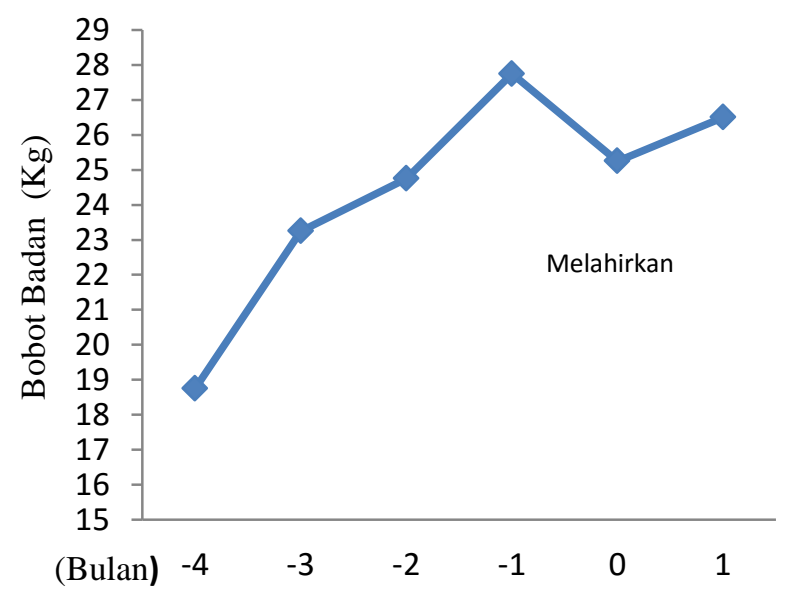

Gambar 2. Pertambahan bobot badan domba Compass Agrinak selama bunting, saat beranak dan awal laktasi 2017

\section{Pertumbuhan Domba Compass Agrinak Pra Sapih}

Domba pra sapih mortalitas sebesar 20\%, 1 ekor dari 5 ekor, hasil ini lebih besar dibandingkan dengan hasil yang dilaporkan Sutama et al. (2012), sebesar $12.5 \%$. Lebih jauh dijelaskan bahwa domba umur 0-2 minggu setelah lahir merupakan masa kritis bagi anak domba, terutama pada pola pemeliharaan ekstensif, kemungkinan terjadi kekurangan susu induk domba. Pada umur 2,5 bulan dan sampai masa pubertas 6-8 bulan pertumbuhan akan berjalan maksimum. Selanjutnya pada saat domba mencapai pubertas, terjadi kembali perlambatan pertumbuhan dan kurva akan kembali landai pada saat mencapai titik belok atau inflection point. Perkembangan bobot badan anak domba pra sapih terlihat pada Gambar 3.

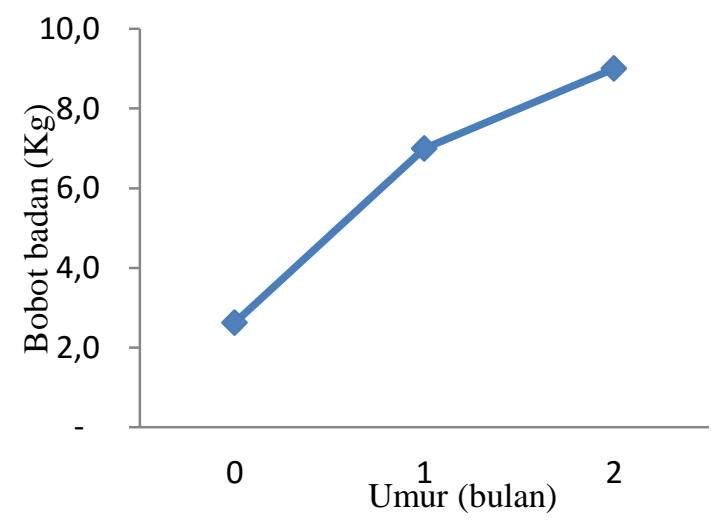

Gambar 3. Perkembangan bobot badan domba Compass Agrinak anak pra sapih

Pada Gambar 3, pertumbuhan domba Compasss Agrinak pra sapih seperti yang ditunjukkan dengan rataan bobot lahir anak sebesar 2,65 $\pm 0,47$, dan rataan bobot badan anak umur 1 bulan sebesar 7,0 $\pm 2,45$ dan pada umur 2 bulan sebesar $9 \mathrm{~kg}$. Hasil yang dicapai pada penelitian ini sedikit lebih tinggi dibandingkan dengan hasil penelitian (Subandriyo et al., 2000), dimana bobot badan domba pada umur 8 minggu mencapai sebesar 6,5 Kg. Domba Compass Agrinak dapat beradaptaasi dengan lingkungan setempat, dan dapat diushakan sebagai usaha pokok. 
Nilai Ekonomi pada Domba Compass Agrinak

Asumsi biaya produksi usaha pemeliharaan domba Compass Agrinak di UPTD Brebes. Biaya pembelian untuk bibit domba Compass Agrinak betina siap bunting sebanyak 8 ekor Rp. 2.600.000,- = Rp. 20.800.000,-,. Biaya pembelian bibit domba Compasss Agrinak jantan sebanyak 2 ekor Rp.3.500.000,- = Rp.7.000.000,-. Biaya untuk pembuatan kandang sebesar Rp. 9.000.000,-/unit. Biaya pembelian peralatan kandang sebesar Rp.560.000,-/tahun. Biaya pembelian obat-obatan sebesar Rp.230.000,/paket tahun. Biaya tenaga kerja dihutung berdasarkan umur setempat diasumsikan sebesar Rp.1.850.000,-/bulan. Kegiatan perbanyakan dan penyebaran bibit domba domba Compass Agrinak, untuk biaya tenaga kerja peternak disubtistusi oleh Dinas Peternakan Kesehatan Hewan Kabupaten Brebes. Biaya penyusutan kandang dihitung sebesar 5\%/tahun sebebsar Rp.450.000,/tahun, penyusutan peralatan sebesar 30\%/tahun sebesar Rp.180.000,-/tahun.

Harga jual domba Compass Agrinal induk apkir sebesar Rp. 2.000.000,- x 2 ekor $=$ Rp.4.000.000,- . Harga jual domba Compass Agrinak jantan apkir sebesar Rp.2.900.000,- x 1 ekor = sebesar Rp. 2.900.000,-. Diasumsikan kelahiran induk domba Compass Agrinak selama pemeliharaan berproduksi 1 ekor induk beranak 1-2 ekor. Jadi 8 ekor indu menghasilkan anak sebanyak 11 ekor, ratarata umur antara 3- 4 bulan. Domba anak dijual sebanyak 4 ekor rata-rata harga sebesar 350.000-400.000,- , harga jual sebesar Rp. 400.000,-/ekor x 4 ekor $=\mathrm{Rp}$. 1.600.000,-.

\section{Biaya Produksi Domba Milik Peternak}

Asumsi biaya produksi usaha pemeliharaan domba milik peternak. Biaya pembelian bibit domba siap bunting sebanyak 2 ekor Rp. 2.500.000,-= Rp. 5.000.000,-. Biaya pembelian bibit jantan sebanyak 1 ekor Rp. 3.000.000,-. Biaya untuk pembuatan kandang sebesar Rp. 2.200.000,-/unit. Biaya pembelian peralatan kandang sebesar Rp.120.000,-/tahun habis pakai dan biaya obat-obatan habis pakai sebesar Rp.50.000,-/tahun/paket. Biaya pembelian pakan konsentrat sebesar Rp.4.500,-/kg x 10 ekor $\times 0,2 \times$ tahun $=$ sebesar Rp. 3.240.000,-/tahun. Biaya tenaga kerja dihutung berdasarkan UMR setempat diasumsikan sebesar Rp.1.850.000,-/bulan. Berdasarkan hitungan waktu kerja peternak selama satu tahun dan diasumsikan sebesar Rp.1.850.000,-/periode usaha. Biaya penyusutan kandang domba di peternak dihitung sebesar 5\%/tahun sebebsar Rp.110.000,-/tahun, penyusutan peralatan dihitung sebesar 120.000,-/tahun habis pakai. Harga jual domba induk apkir sebesar Rp.1.150.000 x 1 ekor = Rp.1.150.000,-.

Harga jual domba jantan afkir sebesar Rp.1.900.000 x 1 ekor = Rp.1.900.000,-/ekor. Kelahiran induk domba selama pemeliharaan berproduksi 1 ekor induk beranak 1-2 ekor. Jadi 2 ekor induk, meghasilkan anak sebanyak 3 ekor rata-rata umur antara 3-4 bulan. Domba dijual sebanyak 2 ekor dengan harga rata-rata sebesar Rp.300.000- Rp.400.000,-/ekor, harga jual sebesar Rp.350.000,-/ekor x 2 ekor sebesar Rp.700.000,-/tahun. Pupuk kandang dikembalikan kelahan pertanian untuk kesuburan tanaman dan hijauan pakan ternak. Analisis ekonomi usaha domba Compass Agrinak dan domba milik peternak terlihat pada Tabel 2.

Tabel 2 menujukkan keuntungan usaha domba Compass agrinek dan domba milik peternak, ada selisih antara tambahan penerimaan hasil penjualan dari jumlah anak pra sapih, induk apkir dan jantan apkir, berdasarkan harga jual. Untuk menghasilkan tambahan output, setiap biaya pengeluaran belanja modal dan biaya produksi yang dikeluarkan oleh UPTD Brebes dapat menghasilkan keuntungan sebesar Rp.1.200.000,-/tahun, B/C 1,1. Usaha domba di peternak, setiap biaya pengeluaran belanja modal dan baya produksi dapat menghasilkan keuntungan sebesar Rp.620.000,-/tahun nilai $\mathrm{B} / \mathrm{C} 1,2$. 
Tabel.2. Analisis ekonomi domba Compass Agrinak di UPTD Brebes

\begin{tabular}{lcc}
\hline \multicolumn{1}{c}{ A. Biaya produksi } & Domba di UPTD (Rp) & Domba peternak (Rp) \\
\hline -Biaya penyusutan kandang & 1.800 .000 & 110.000 \\
-Biaya penyusutan peralatan & 180.000 & 120.000 \\
-Biaya obat-obatan/paket & 230.000 & 50.000 \\
-Biaya pakan konsentrat & 3.240 .000 & \\
-Biaya tenaga kerja peternak & 1.850 .000 & 1.850 .000 \\
-Jumlah & 7.300 .000 & 2.130 .000 \\
\hline \multicolumn{1}{c}{ B. Hasil penjualan } & & 1.900 .000 \\
\hline -Harga jual ternak domba jantan apkir & 2.900 .000 & 1.150 .000 \\
-Harga jual ternak domba betina apkir & 4.000 .000 & 700.000 \\
-Harga jual anak pra sapih & 1.600 .000 & 2.750 .000 \\
Jumlah pendapatan & 8.500 .000 & 620.000 \\
Jumlah pendapatan bersih & 1.200 .000 & 1,2 \\
B/C & 1,2 & \\
\hline
\end{tabular}

Keterangan: ternak domba masih di UPTD Brebes dan di peternak sebagai investasi

Domba Compass Agrinak dapat berproduksi dan secara ekonomi layak untuk dikembangkan. Domba milik peternak secara ekonomi belum layak, karena peternak cara usahanya bersipat sampingan dan usaha pokoknya adalah bertani.

\section{KESIMPULAN}

Ternak domba Compass Agrinak merupakan salah satu rumpun domba hasil rekayasa teknologi breeding dari Balai Penelitian Ternak Bogor. Pengembangan domba dilakukan melalui kelembagaan UPTD, milik Dinas Peternakan dan Kesehatan Hewan Kabupaten Brebes Jawa Tengah. Performan domba induk bunting dan induk habils beranak serta anak pras sapih relatif cukup, dan ditandai dengan meningkatnya pertambahan bobot badan. Mengindikasikan domba Compass Agrinak yang ada di UPTD Brebes dapat berkembang baik, pada agroekosistem dataran tinggi. Hal ini menjadi informasi penting bagi upaya pengembangan domba Compass Agrinak, sebagai bibit. Lebih lanjut untuk dapat disebarluaskan kepada masyarakat peternak domba, sehingga dapat diusahakan sebagai usaha pokok maupun sampingan. Diharapkan domba milik peternak dapat diganti dengan domba hasil teknologi UPTD Brebes yaitu domba Compass Agrinak.

\section{DAFTAR PUSTAKA}

Almahdy, H., W. Tess, E. El-Tawil, E. Shehata , H. Mansour. 2000. Evaluation of Egyptian sheep production systems: I. Breed crosses and management systems. J. Anim. Sci. 78:283-287.

Astuti, M., 1993. Parameter Produksi Kambing dan Domba di Daerah Dataran Tinggi Kec. Tretep Kab. Temanggung. Prosiding: Pertemuan Ilmiah Penelitian Ruminansia Kecil. Bogor, Indonesia. 2223 Nopember 1983.

Dinas Peternakan dan Kesehatan Hewan Kabupaten Brebes. 2017. Sektor pertanian di Kabupaten Brebes dapat memberikan kontribusi terhadap sektor peternakan diambil dari hasil limbah pertaniannya.

Gopar. 2012. Produktivitas domba lokal (ovis aries) yang diberi ransum bersuplement zeolit dan urea (Skripsi) Fakultas Agribisnis dan Teknologi Pangan, Universitas Djuanda. Bogor.

Handiwirawaan, E., R. R. Noor, C. Sumantri dan Subandriyo. 2012. Hubungan tingkah laku dengan sifat-sifat produksi. JITV 17(3):179-188.

Handarini, R., D. Sudrajat, dan A. Prasetyo. 2016. Performa domba lokal yang diberi konsentrat berbasis limbah agroindustri selama masa kebuntingan. Research 
Report, Seminar Nasioanal dan Gelar Produk. 133-142. http://researchreport.umm.ac.id/index.php/researchreport/article/view/748/977

Isbandi. 2013. Pembentukan kampung ternak domba sebagai upaya mendekatkan teknologi peternakan kepada Masyarakat. Wartazoa 23(3):115-121.

Lupton. C. J. 2008. ASAS Centtennial paper: Impacts of animal science reseatch on United states sheep production and predictions for the future. K. Anim. Sci. 86: 3252-3274.

Saepul, M. S.,T. Rohayati dan I. Hermanan. 2018. Pengaruh imbangan protein dan energi terhadap ferporma domba garut betina. Universitas Garut. Jurnal Ilmu Peternakan. 2 (2): 22-31.

Rusdiana, S., dan H. Rijanto. 2014. Penigkatan usaha ternak kambing di kelompok tani Sumbersari dalam analisis ekonomi. Program Studi Agribisnis Fakultas Pertanian UNS, Jurnal Sosial Ekonomi Pertanian Agribisnis. 11(1):151-162.

Rusdiana, S. dan L. Praharani. 2015. Peningkatan usaha ternak domba melalui diversifikasi tanaman pangan, analisis pendapatan peternak. Jurnal Agroekonomika. 4 (1): 80-95.

Sutama, I. K., 1991. Production Aspects of Javanese Fat-Tail Sheep in Indonesia: Production and Reproductive Performance of Javanese Fat-Tail Sheep.
In: Proceeding of a Workshop in Surabaya, Juni 1991, Pp.231-238.

Saputra. 2008. Penampilan reproduksi induk dan pertumbuhan anak domba lokal. [Internet] [di akses 18 April 2019]. Tersedia dari repository.ipb.ac.id/.../D11nek /jurnal /_BAB\%20II.\% 20Tinjauan\%20.pdf.

Suhardi. 2010. Aplikasi teknologi pengolahan pakan konsentrat ternak ruminansia dengan metode pengukusan untuk meningkatkan tingkat kecernaan pakan dan pertambahan bobot badan harian. Jurnal Teknologi Peternakan Mulawarman. 6 (1):15-19.

Santi, N. E. K. 2011. Penampilan reproduksi induk dan pertumbuhan anak domba lokal yang mendapat ransum dengan sumber karbohidrat jagung dan onggok. Skripsi, Fakultas Peternakan. Institut Pertanian Bogor.

Sutama, I. K, I. G. M Budiarsana, S. Supriyati, dan Hastono. 2012. Perlakuan Progesteron Eksogenus Selama Bunting untuk Meningkatkan Produksi Susu dan Pertumbuhan Anak pada Kambing Peranakan Etawah. JITV. 1(2):83-91.

Wardhani, D. K. 2006. Performans domba lokal yang digembalakan di padang rumput Brachiaria humidicola UP3 Jonggol dan penambahan dedak padi. [Internet] [Diakses 19 April 2019]. Tersedia dari https://repository.ipb.ac.id/jspui/.../D11p $\mathrm{ku} / \mathrm{jurnal} /$ daftar pustka\%20.pdf 